\title{
Maintaining a happy face: stable colour polymorphism in the spider Theiridion grallator (Araneae, Theridiidae)
}

\author{
Rosemary G. Gillespie and \\ Bruce E. Tabashnik
}

\author{
Departments of Zoology and Entomology, \\ University of Hawaii, Honolulu, HI 96822, U.S.A.
}

\begin{abstract}
Theridion grallator is a highly polymorphic spider endemic to the wet and mesic forests of the Hawaiian Islands. The frequencies of the two major morph classes, patterned and unpatterned abdomen, did not show significant spatial or temporal variation within undisturbed or disturbed areas on Maui. Similarly, morph frequencies did not vary significantly between undisturbed areas on three different islands. Estimates of spider migration suggest that gene flow is sufficient to account for the similarity in frequency within and between areas on Maui, but it is probably not sufficient to explain the similarity among islands. Fecundity did not differ between morphs. A significant inverse relationship between morph frequency and residence time in certain cases suggests that frequency-dependent selection, perhaps mediated by bird predation, may play a role in maintaining the polymorphism.
\end{abstract}

\section{INTRODUCTION}

Polymorphism has long fascinated ecological geneticists, as it offers the opportunity to study evolution in action. It may be caused by certain types of selection (heterosis, temporally fluctuating or frequency-dependent selection), migration, or stochastic processes (Ford, 1975; Kimura, 1983). In disturbed environments polymorphisms may reflect historical selection and present neutrality and/or novel directional selection. Numerous cases of transient and stable polymorphism of genes affecting pigmentation have now been found in diverse groups, including snails (Clarke et al., 1978), butterflies (Turner, 1977), moths, beetles (Bishop and Cook, 1980) and spiders (Gunnarsson, 1985; Oxford, 1976; Oxford and Shaw, 1986; Reillo and Wise, 1988a, $b$ ).

Colour polymorphism in spiders is a widespread phenomenon, but few studies have attempted to analyse the factors responsible for its presence or maintenance. One of the two spiders in which this problem has been addressed is the small theridiid, Enoplognatha ovata. This spider exhibits three distinct morphs (Locket and Millidge, 1953; Hippa and Oksala, 1979; Oxford, 1976), which are controlled by three alleles at an autosomal locus (Oxford, 1983; Reillo and Wise, 1988c). Morph frequencies of this species exhibit temporal stability, but considerable variability between colonies only short distances apart (Oxford, 1976; Reillo and Wise, 1988b). Oxford and Shaw (1986) found that morph frequencies of $E$. ovata in their study site in England (to which the species is native) are converging towards a general equilibrium. Some type of weak selection is implicated, in addition to migration and genetic drift. At a local level, Reillo and Wise (1988 $a, b)$ found no evidence for selection on morph frequencies in the eastern U.S. (where the spider has been introduced); they attributed patterns of morph frequency variation to the effects of migration and genetic drift.

The only studies that have identified selective agents responsible for maintaining a polymorphism in spiders are those of Gunnarsson (1985, 1987). Gunnarsson examined colour morphs of Pityohyphantes phrygianus (Araneae: Linyphiidae) and showed that morph frequencies are balanced by opposing selective pressures: melanic forms have an activity advantage over non-melanics at low temperatures; at the same time, this renders them more vulnerable to predation.

The present study examined colour variability in the Hawaiian happy face spider, Theridion grallator (Araneae, Theridiidae), a small $(<5 \mathrm{~mm}$ 
long) resident of wet (annual rainfall 200 to $350 \mathrm{~cm}$ ) and mesic (annual rainfall 100 to $200 \mathrm{~cm}$ ) forests of the Hawaiian Islands (Gon, 1985). It has long, slender legs and a smooth translucent yellow body. The base colour of the abdomen is pale translucent yellow, but a variety of abdominal colour patterns may be superimposed on this background (Gon, 1985). The polymorphism is controlled by one locus, with alleles for patterned morphs dominant over alleles for the unpatterned (Gillespie and Tabashnik, 1989). Patterns may be red, maroon, black or white, and vary considerably in form and extent. For the purpose of this paper, the morphs were categorised as either unpatterned (no superimposed pigment) or patterned (some superimposed pigment).

In this study we examined temporal and spatial patterns of morph frequencies in $T$. grallator, and possible factors responsible for the presence and maintenance of the polymorphism. (1) Temporal and spatial variation in morph frequencies at different subsites within one site that included native and disturbed forest. Similar morph frequencies here could suggest selection, but migration between subsites could not be ruled out. We therefore also estimated migration between subsites, and morph frequencies between isolated sites. (2) Migration within a site, between subsites. If this was sufficiently high, it could explain similarities in morph frequencies between subsites. (3) Variation in morph frequency between islands, in undisturbed sites. Because gene flow among islands is expected to be low, similar frequencies on different islands would imply that selection was important and relatively uniform across islands. Variation among islands would suggest genetic drift, differential selection pressures, or a combination of both. We also measured: (4) Fecundity of unpatterned versus patterned females. We examined the hypothesis that differences in offspring numbers play a role in maintaining the polymorphism. This could occur if females of one morph type lay more eggs than another. In the final part of the study we tested the possible role of frequency-dependent selection in maintaining the polymorphism: (5) Relationship between morph frequency and residence time. We used natural low-level fluctuations in morph frequency to test the stability of the polymorphism, using residence time (deviations from the average) as an indicator of survival. Shifts from the equilibrium morph frequency should result in lowered survival for the morph that was in excess, if frequency-dependent selection were operating.

\section{METHODS}

\section{Study organism}

T. grallator inhabits the underside of leaves of a variety of plants, especially the native Broussaisia arguta (Saxifragaceae) and Clermontia arborescens (Campanulaceae). It is also found on the introduced ginger, Hedychium coronarium (Zingiberaceae). The webs are inconspicuous, scantily covering the underside of a leaf. Feeding is primarily nocturnal, and the most common prey items are dipterans of the families Dolichopodidae and Drosophilidae (Gon, 1985). During daylight hours spiders are usually found flat against the underside of a leaf. Generally, except for the case of maternal females with offspring, a single individual only is found under a leaf. $T$. grallator exhibits an annual life cycle. Egg sacs are mostly laid between May and July, with young dispersing in the later summer (see Gon, 1985; Gillespie and Tabashnik, 1989 for additional information).

\section{Field sites}

Undisturbed sites were located in Maui (the Nature Conservancy of Hawaii's Waikamoi Preserve, elevation $1360 \mathrm{~m}$ ), Molokai (the Nature Conservancy of Hawaii's Kamakou Preserve, elevation $1110 \mathrm{~m}$ ) and Hawaii (Thurston, in Volcanoes National Park, elevation $1190 \mathrm{~m}$ ). These were all sites of native Hawaiian wet-to-mesic forest, with a canopy dominated by Metrosideros polymorpha (Myrtaceae) and Acacia koa (Leguminosae); the sub-canopy by Broussaisia arguta (Saxifragaceae), Clermontia arborescens (Campanulaceae), Cheirodendron trigynum (Araliaceae), Coprosma sp. (Rubiaceae), Ilex anomolum (Aquifoliaceae), Myrsine spp. (Myrsinaceae) and Pelea spp. (Rutaceae).

A disturbed site was located in an area of Maui (Makawao State Forest, near Waikamoi Preserve, elevation $1350 \mathrm{~m}$ ) which had many introduced plants (grasses, blackberry and ginger in particular), mammals (especially pigs, mongoose and mice) and birds (including Leiothrix lutea, Lonchura punctulata and Zosterops japonica). $T$. grallator was found here on the introduced ginger, $H$. coronarium.

\section{Temporal and spatial variation in morph frequencies}

The site on Maui (with undisturbed and disturbed areas) was divided into subsites of $100-200 \mathrm{~m}^{2}$ separated by $300-900 \mathrm{~m}$, which reflected the 
clumped distribution of the spider's preferred host plants, B. arguta and C. arborescens in undisturbed forest, and $H$. coronarium in the disturbed area. In the three undisturbed subsites (labelled 1-3) and the four disturbed subsites (labelled 4-7), morph frequencies were determined from a 1-day sampling period of 50 individuals at each subsite between March and April 1988. Two subsites (undisturbed subsite 1 and disturbed subsite 4) were monitored from September 1987 until April 1988. The proportion of unpatterned to patterned morphs ( $n=50-70$ individuals) was determined in the middle of each month. Chi-square tests were used to determine differences in morph frequencies between different sites and subsites.

\section{Migration}

Migration into subsites on Maui was estimated in both undisturbed and disturbed areas. In the undisturbed area, a clump of $B$. arguta was located at approximately $300 \mathrm{~m}$ from subsite $1, T$. grallator inhabitants were removed, and the undersides of six leaves were coated with Stickem ${ }^{\mathrm{TM}}$, a nondrying sticky substance. Similarly, in the disturbed area, a clump of $H$. coronarium was located approximately $600 \mathrm{~m}$ from subsite 4 , any $T$. grallator were removed, and the underside of six leaves coated with Stickem. Trapped spiders were picked off the leaves every second day from September 1987 to August 1988. When sticky leaves senesced, the leaf closest to them was coated with Stickem, so that six coated leaves were always present at each sampling area.

Based on previous evidence that morph type is controlled by a single locus, with alleles for the patterned morphs dominant to unpatterned (Gillespie and Tabashnik, 1989), and the assumption that the alleles are in Hardy-Weinberg equilibrium, we calculated allele frequencies for each subsite. We used these allele frequency estimates to calculate $F_{S T}$, the fixation index, which is the heterozygosity of a subpopulation due to random genetic drift (Hartl, 1988). We then estimated $\mathrm{Nm}$, the number of migrants per generation, from $F_{S T}$ as follows:

$$
N m=\left(1 / F_{S T}-1\right) / 4 \quad(\text { Hartl, 1988). }
$$

These calculations assume that selection does not influence the polymorphism; i.e., gene flow is the only factor restricting differentiation among subpopulations. $\mathrm{Nm}$ is the number of migrants that would be needed to account for the observed morph frequencies at the different subsites.
Variation in morph frequency between islands

Morph frequencies of $T$. grallator (patterned versus unpatterned) were determined at undisturbed sites on three islands. This allowed us to determine the ubiquity and stability of the polymorphism in largely isolated areas. T. grallator were located by thorough scrutiny of the leaves of all of the largerleaved plants in a site. Spiders were censused by going through the area systematically, turning over each leaf in turn and one time only. Data were collected from a single day's sample at each site. The colour and size of individuals (both mature and immature) were recorded for different plant species to estimate the frequency of the different morphs. Chi-square tests were used to test for heterogeneity in morph frequencies among sites. We also calculated allele frequencies for each island, and used the frequencies to estimate $F_{S T}$ and $\mathrm{Nm}$ as described above. Here $\mathrm{Nm}$ represents the number of migrants per generation between islands that would be needed to account for the observed morph frequencies on the different islands, assuming that the polymorphism is neutral.

\section{Fecundity of unpatterned versus patterned females}

We examined the possibility of differences in fecundity between patterned and unpatterned morphs. All females with egg sacs (in both disturbed and undisturbed areas) were marked and monitored. The number of offspring produced by unpatterned and patterned females were counted immediately after the eggs hatched.

\section{Relationship between morph frequency and residence time}

Using natural fluctuations in morph frequencies, we examined the possibility of frequency-dependent selection by testing whether the frequency of a given morph in a population affected its residence time at a subsite. Because we could not separate emigration from mortality, we use the term "residence" rather than "survival".

At any given subsite morph frequencies fluctuated by approximately \pm 10 per cent. We examined the relationship between morph frequency and morph residence time. A significant negative relationship would suggest that frequency-dependent or temporally varying selection plays a role in maintaining the polymorphism in $T$. grallator. 
Tests were done in (a) an undisturbed area, and (b) a disturbed area:

(a) The undisturbed area was a $5 \mathrm{~m}^{2}$ area in subsite in the Waikamoi Preserve in Maui. Three plants of B. arguta, occupied by a large number of spiders (40-50 per cent of the leaves occupied) were selected in October 1987, and the spiders $(n=44)$ were marked with a small dot of paint on one leg to allow identification of individuals. Spiders were repainted following moulting. When the apparent disappearance of a painted individual from a subsite was coupled with replacement on its leaf by a similar unmarked individual, we assumed that the former had moulted into the latter. Spider densities remained relatively constant through January 1988, but began to decline to very low levels in Spring (5-8 per cent of the leaves occupied). From February to April 1988 populations were composed almost entirely of mature animals.

(b) The highly disturbed area was a $10 \mathrm{~m}^{2}$ area in subsite 5 in the Makawao State Forest, elevation $1350 \mathrm{~m}$, where $T$. grallator was found at high density (40-45 per cent of the leaves occupied) on the introduced ginger, $H$. coronarium. Spiders were marked and monitored from the beginning of November 1987 until late January 1988.

Tests were divided into one week intervals. At the outset of each week, the frequency of unpatterned and patterned morphs was determined. Individuals were then monitored every 2-3 days in the subsequent 7 -day period to determine how long they remained in the subsite. Tests were conducted on alternate weeks from November 1987 to March 1988.

We used regression analysis (Sokal and Rohlf, 1981 ) to test for a significant relationship between morph frequency and residence time at each subsite. At the undisturbed subsite, separate analyses were conducted for periods when spider density was high (40-50 per cent leaves occupied; October 1987 through January 1988) and when it was low (5-8 per cent of the leaves occupied; February to April 1988).

\section{RESULTS}

\section{Temporal and spatial variation in morph frequencies}

Morph frequencies did not show significant spatial or temporal variation at undisturbed or disturbed areas on Maui. Morph frequencies did not vary significantly among three subsites in an undisturbed area (Chi-Square $=0 \cdot 4, \mathrm{df}=2, P=0.82$ ) nor among four subsites in a disturbed area (ChiSquare $=4 \cdot 4, \mathrm{df}=3, P=0 \cdot 22$ ) on Maui (table 1). Further, the mean frequency of unpatterned morphs did not differ significantly between undisturbed (mean $72 \cdot 2 \pm 4.5$ per cent) and disturbed (mean $66 \cdot 7 \pm 7 \cdot 5$ per cent) areas $(t=0 \cdot 57, \mathrm{df}=5$, $P=0.59)$. Variation in morph frequencies during a 7 -month period was not significant at a single undisturbed (Chi-Square $=2 \cdot 63, \mathrm{df}=6, P=0.85$ ) or disturbed (Chi-Square $=2 \cdot 43, \mathrm{df}=6, P=0.88$ ) subsite (fig. 1).

Table 1 Morph frequencies in disturbed and undisturbed areas on Maui

\begin{tabular}{|c|c|c|c|c|c|}
\hline \multirow[b]{2}{*}{ Subsite } & \multirow[b]{2}{*}{$\mathbf{n}$} & \multirow{2}{*}{$\begin{array}{l}\text { Unpatterned } \\
q^{2}\end{array}$} & \multirow{2}{*}{$\begin{array}{l}\text { Patterned } \\
p^{2}+2 p q\end{array}$} & \multicolumn{2}{|c|}{ Gene freq. } \\
\hline & & & & $q$ & $p$ \\
\hline \multicolumn{6}{|l|}{ Undisturbed } \\
\hline Subsite 1 & 15 & 0.80 & $0 \cdot 20$ & 0.89 & $0 \cdot 11$ \\
\hline Subsite 2 & 31 & 0.65 & 0.35 & $0 \cdot 80$ & $0 \cdot 20$ \\
\hline Subsite 3 & 43 & 0.72 & $0 \cdot 28$ & $0 \cdot 85$ & $0 \cdot 15$ \\
\hline Mean & & 0.72 & $0 \cdot 28$ & 0.85 & $0 \cdot 15$ \\
\hline \multicolumn{6}{|l|}{ Disturbed } \\
\hline Subsite 1 & 22 & 0.73 & $0 \cdot 27$ & $0 \cdot 85$ & $0 \cdot 15$ \\
\hline Subsite 2 & 60 & 0.45 & 0.55 & 0.67 & $0 \cdot 33$ \\
\hline Subsite 3 & 20 & 0.70 & $0 \cdot 30$ & 0.84 & $0 \cdot 16$ \\
\hline Subsite 4 & 24 & 0.79 & $0 \cdot 21$ & 0.89 & $0 \cdot 11$ \\
\hline Mean & & 0.67 & $0 \cdot 33$ & $0 \cdot 81$ & $0 \cdot 19$ \\
\hline
\end{tabular}

\section{Migration}

The data from the sticky leaves revealed some immigration into subsites from which $T$. grallator had been removed. On $B$. arguta, a total of 14 $T$. grallator (comprising 0.26 per cent of all arthropods caught) were trapped between September 1987 and August $1988 \quad(1.8$ immigrants/leaf/year). None of these was marked. Except for one mature female, and one immature, all were mature males, 50 per cent being trapped between March and May, the peak of sexual activity. On $H$. coronarium, a total of six $T$. grallator $(0.06$ per cent of all arthropods caught $)$ were trapped between December and August (1.4 immigrants/leaf/year). Again, none were marked. Five were mature males.

We calculated $F_{S T}$, heterozygosity due to random genetic drift, and estimated $\mathrm{Nm}$, the number of migrants that would be needed to account for the observed morph frequencies at the different subsites. The estimate for $\mathrm{Nm}$ at undisturbed subsites was $23\left(F_{S T}=0.0108\right)$; at disturbed subsites the $N m$ value was $5\left(F_{S T}=0.0464\right)$. 


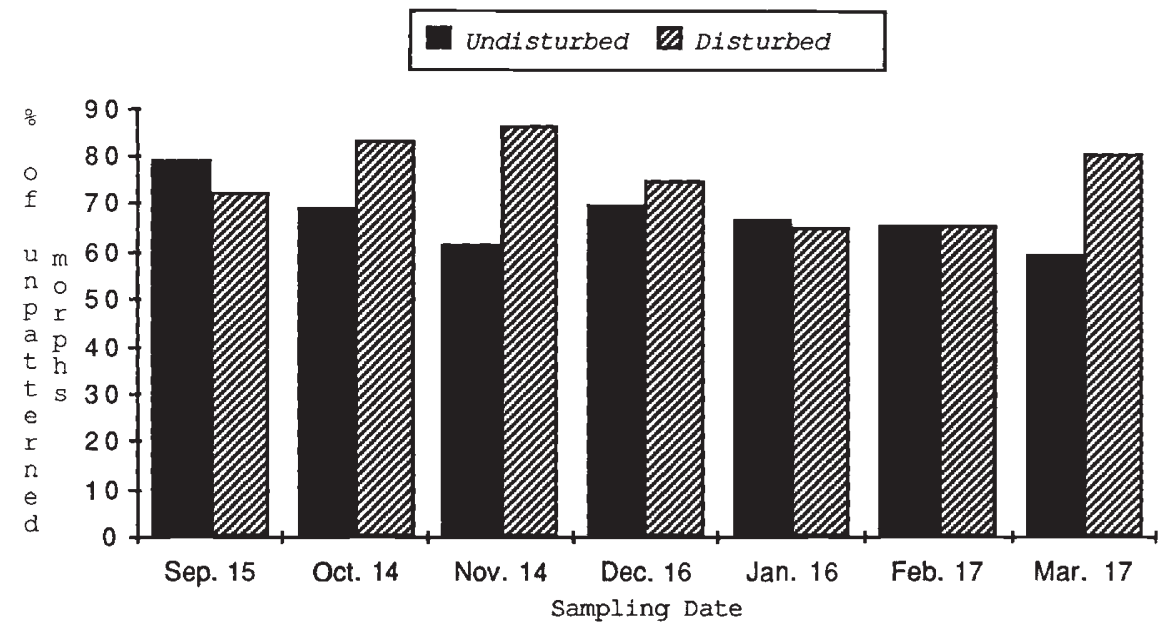

Figure 1 Morph frequency fluctuations over a 7-month period. The percentage of unpatterned morphs at an undisturbed subsite (Broussaisia) and a disturbed subsite (Hedychium) from Sep. 1987 to Mar. 1988.

\section{Variation in morph frequency between islands}

Morph frequencies of $T$. grallator in undisturbed areas did not vary significantly among the islands of Maui, Molokai and Hawaii (Chi-Square = $0 \cdot 26, \mathrm{df}=2, P=0 \cdot 88$, table 2 ).

Table 2 Morph frequencies at undisturbed areas on different islands

\begin{tabular}{lcll}
\hline $\begin{array}{l}\text { Island } \\
\text { (Site) }\end{array}$ & $n$ & Unpatterned & Patterned \\
\hline $\begin{array}{l}\text { Maui } \\
\text { (Waikamoi) }\end{array}$ & 41 & 0.68 & 0.32 \\
$\begin{array}{l}\text { Molokai } \\
\text { (Kamakou) }\end{array}$ & 35 & 0.66 & 0.34 \\
$\begin{array}{l}\text { Hawaii } \\
\text { (Thurston) }\end{array}$ & 22 & 0.62 & 0.38 \\
\hline
\end{tabular}

The estimated value for $F_{S T}$ was 0.0015 , which yielded an estimate of 169 for $\mathrm{Nm}$. These results imply that a gene flow of 169 migrants per island per generation would be required to maintain the degree of similarity in morph frequency observed among islands, assuming that the polymorphism was not influenced by selection.

\section{Fecundity of unpatterned versus patterned females}

There was no significant difference in the number of offspring between unpatterned (mean 16.00, SD: 10.93 ) and patterned females (mean 20.30, SD: $12 \cdot 55)(t$-test: $t=0 \cdot 60, \mathrm{df}=16, P=0 \cdot 56)$.

\section{Relationship between morph frequency and residence time}

\section{Undisturbed area}

When the population density was high (40-50 per cent leaves occupied), the proportion of unpatterned morphs ranged from 70.0 to 90.5 per cent. For each morph, residence time was negatively correlated with relative abundance (fig. 2).

When the population density was low (February to April 1988; 5-8 per cent of the leaves occupied), there was no significant relationship between residence time and morph frequency (for patterned morphs, slope $=-2 \cdot 8, R^{2}=0 \cdot 14, F_{[1,7]}=$ $1 \cdot 10, P=0.33$; for unpatterned morphs, slope $=$ $\left.-2 \cdot 6, R^{2}=0 \cdot 41, F_{[1,7]}=1 \cdot 84, P=0 \cdot 21\right)$.

\section{Disturbed area}

The population density here ranged from 10-25 per cent of leaves occupied. The proportion of unpatterned morphs ranged from 43.0 to 65.0 per cent. Residence time showed no correlation with relative abundance for either morph (fig. 3).

\section{DISCUSSION}

Both patterned and unpatterned colour morphs have been found in all populations of $T$. grallator studied to date (Gillespie and Tabashnik, 1989). The current study found no significant spatial variation between or within islands in the frequencies of these morphs. Further, no significant temporal 


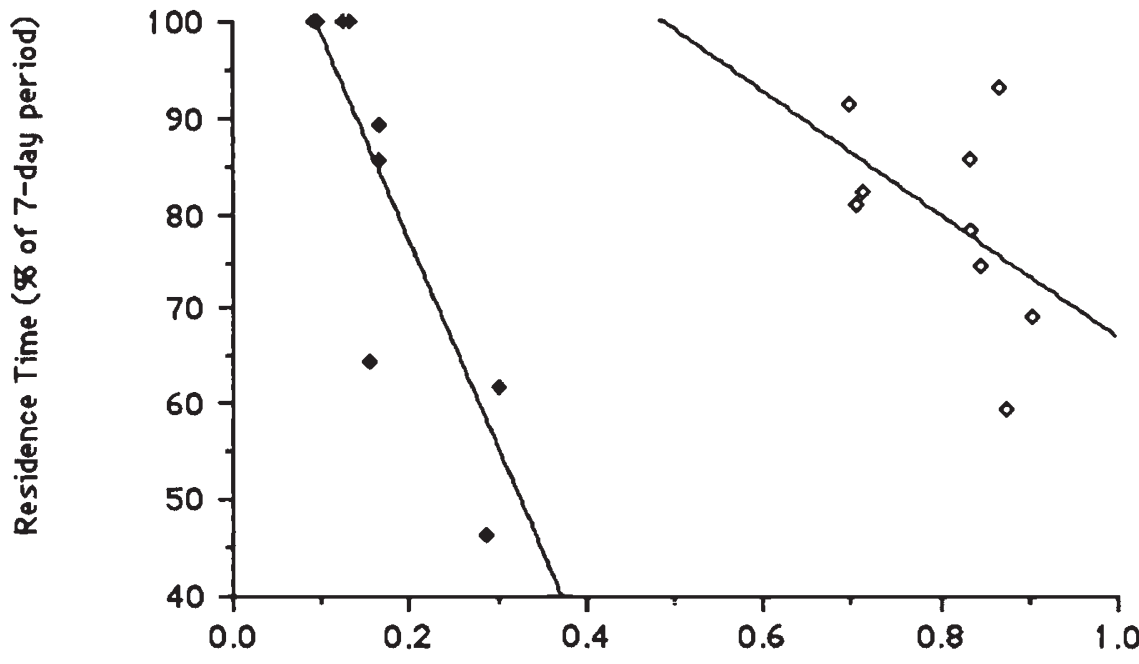

Morph Frequency

Figure 2 Effect of morph frequency on residence time of unpatterned and patterned morphs in populations in an undisturbed area at high spider density. The percentage of the 7-day period that a spider remained at the subsite is shown for the separate morphs, as a function of the morph frequency at the beginning of the time period ( $\bullet$ for patterned morphs, $\diamond$ for unpatterned morphs). Residence times demonstrated a significant inverse relationship to their frequency for both morph types. For patterned morphs, slope $=-215 \cdot 6, R^{2}=0.76$ (ANOVA: $F_{[1,9]}=25 \cdot 69, P<0 \cdot 001$ ). For unpatterned morphs, slope $=-78 \cdot 8, R^{2}=0 \cdot 45$ (ANOVA: $\left.F_{[1,7]}=5 \cdot 60, P<0 \cdot 05\right)$.

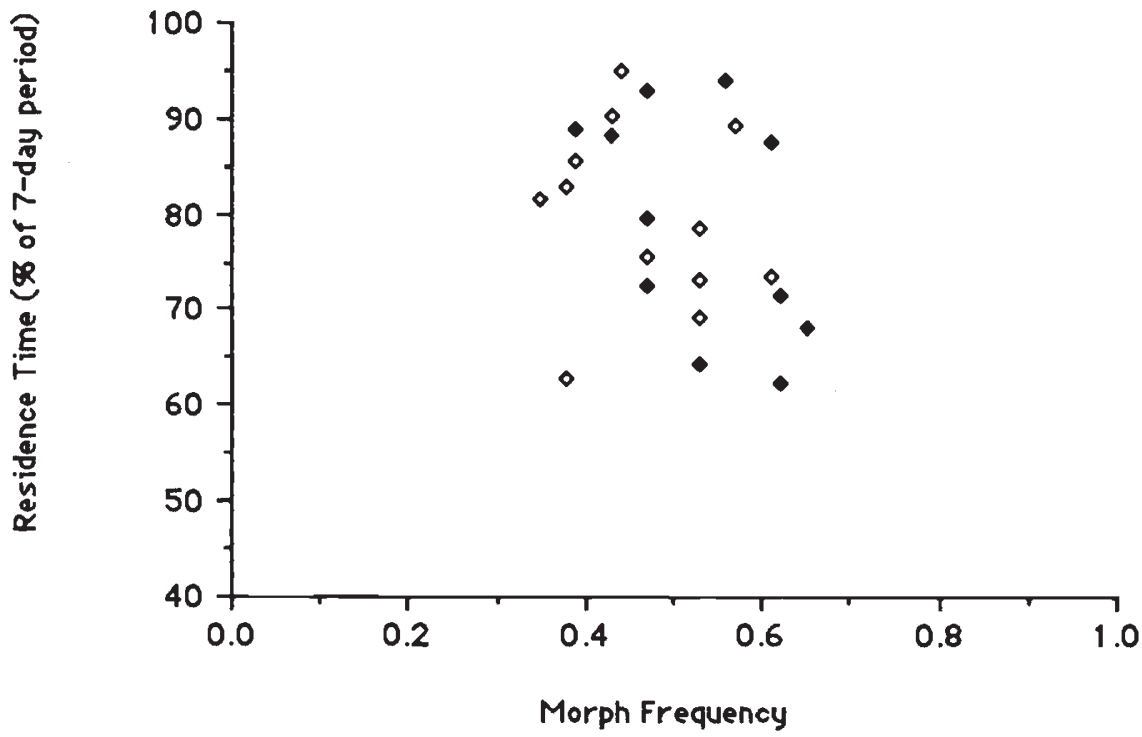

Figure 3 Effect of morph frequency on residence time of unpatterned and patterned morphs in populations in a disturbed area. $\checkmark$ for patterned morphs, $\diamond$ for unpatterned morphs. Regression analysis: For patterned morphs, slope $=-60 \cdot 1, R^{2}=0 \cdot 19$, ANOVA: $F_{[1,10]}=2 \cdot 43, P>0 \cdot 10$; for unpatterned morphs, slope $=-19 \cdot 2, R^{2}=0 \cdot 03$, ANOVA: $F_{[1,10]}=0 \cdot 31, P>0 \cdot 10$. 
variation was detected in 7-month studies of two populations. How can we explain both the existence of the polymorphism and its stability?

Repeated founder events and genetic drift have been used to explain the presence of the polymorphism in the spider Enoplognatha ovata, and its considerable spatial variability on a local scale (Reillo and Wise 1988a). E. ovata bears a striking resemblance to $T$. grallator in its colour polymorphism (Gillespie and Tabashnik, 1989). In $T$. grallator, the finding of similar morph frequencies in different subsites on Maui could be explained by extensive gene flow between these populations. Estimates of $\mathrm{Nm}$ indicate that 23 immigrants per population per generation would be needed to account for the observed morph frequencies at the undisturbed subsites, five at the disturbed subsites. Our estimates from the sticky leaves indicate that immigration from all sources into undisturbed and disturbed subsites was extensive (1.8 immigrants/leaf/year on B. arguta. 1.4 immigrants/leaf/year on $H$. coronarium), which suggests that gene flow between subsites is probably sufficient to account for the similarity in morph frequencies between subsites.

It is highly unlikely, however, that gene flow among islands is sufficient to maintain the degree of similarity in morph frequencies observed among islands. Assuming that gene flow is the only factor restricting differentiation in morph frequency among islands, the number of migrants needed to account for the observed morph frequencies appears to be unreasonably high $(\mathrm{Nm}=169$ spiders per island per generation). These results imply, therefore, that the similarity in morph frequency among islands is maintained, at least in part, by selection. These results further suggest that similar selection occurs on each island.

Types of selection that could maintain the polymorphism in $T$. grallator include balancing selection, heterosis, frequency-dependent selection and temporally varying selection. In $E$. ovata, significant fecundity differences have been detected between morphs in certain populations, and may play a role in maintaining the polymorphism of this species by balancing selection on other features of a morph (Reillo and Wise, 1988b). However, no differences in fecundity were detected in $T$. grallator.

We examined the possible role of selection in the polymorphism of $T$. grallator through the effect of naturally varying morph frequencies on residence period. The results indicated a significant negative relationship between the frequency of a morph at any one time and its residence, but only in an undisturbed area where spider density was high. If we assume that emigration was independent of morph type and frequency, this might suggest frequency-dependent selection.

One of the most likely potential agents that could induce fluctuating selection pressure on $T$. grallator is bird predation. The development of a search image is a common phenomenon in birds (Clarke, 1962; Allen, 1974, 1976; Murdoch and Oaten, 1975; Atkinson and Warwick, 1983; Greenwood, 1984; but see Guilford and Dawkins, 1987). As a result, their foraging intensity in a given area may vary with the frequency and/or abundance of their prey. Drepanidine birds (Fringillidae) coexist with $T$. grallator in Hawaii. They are obligate or facultative insect gleaners (Scott et al., 1986; Pimm and Pimm, 1982) and have long been recognized as important predators of spiders (Perkins, 1913). They have been observed searching the undersides of $B$. arguta leaves on several occasions (personal observation). It may be that when patterned morphs of $T$. grallator are rare, they are favoured; as they become more numerous, birds develop a search image towards them, and they suffer higher predation. Further, populations of $T$. grallator exist in discrete patches. In such situations, avian predators tend to confine their foraging effort to a single patch before moving to another (Oaten, 1977). Therefore, the search image of a bird could be significantly altered by changes of morph frequency of $T$. grallator even within a single patch.

We should give some consideration to the absence of any significant relationship between the frequency of a morph and its residence in disturbed areas and in areas where spider densities were low. One possible explanation would be reduced predation. In disturbed areas spiders are found on $H$. coronarium, a plant with large, slippery leaves that may well restrict predation. Further, when a prey species is very scarce, predator search images tend to be lost (Murdoch and Oaten, 1975). Thus, when spider density is low, frequency-dependent selection may be weak or absent. On the other hand, there was no significant difference in morph frequency between undisturbed and disturbed subsites. This could be explained by migration between the undisturbed and disturbed subsites.

We have shown here that the polymorphism of $T$. grallator is ubiquitous and morph frequencies appear to be balanced. Frequency-dependent selection is implicated in both the exhibition and stability of the polymorphism. However, alternative explanations cannot be ruled out. Further study is needed to definitively pinpoint the 
mechanisms responsible for maintaining the polymorphism.

Acknowledgements The study was inspired and instigated through the work of Sam Gon. It would have been impossible without an enormous amount of help from the Nature Conservancy of Hawaii: Rob Rydell encouraged the initial efforts; Alan Holt, Paul Higashino and Mark White allowed progress to continue throughout the year; the work on Molokai would have been impossible without the help of Ed Misaki. Dr Lloyd Loope and Art Medeiros (Haleakala National Park) gave immense support and encouragement throughout the study. Thanks also to Bill Mull for invaluable advice and discussion, to Geoff Oxford and Jay Rosenheim for useful comments on the first draft, and to John Bordley and the University of the South for use of computer equipment. Chris Parrish helped in completion of the study. The work was funded by Whitehall Foundation grant J86-47, with additional support from the Nature Conservancy of Hawaii, the National Park Service, and a Fujio Matsuda Scholar Award from the University of Hawaii Foundation.

\section{REFERENCES}

ALLEN, J. A. 1974. Further evidence for apostatic selection by wild passerine birds: training experiments. Heredity, 33, 361-372.

ALLEN, J. A. 1976. Further evidence for apostatic selection by wild passerine birds: 9-1 experiments. Heredity, 36, 173180.

ATKINSON, W. D. AND WARWICK, T. 1983. The role of selection in the colour polymorphism of Littorina rudis Maton and Littorina arcana Hannaford-Ellis (Prosobranchia: Littorinidae). Biol. J. Linn. Soc., 20, 137-151.

BISHOP, J. A. AND COOK, L. M. 1980. Industrial melanism and the urban environment. Adv. Ecol. Res., 11, 373-404.

CLARKE, B. 1962. Balanced polymorphism and the diversity of sympatric species. In Nichols, D. (ed.) Taxonomy and Geography, Systematics Association, Oxford, pp. 47-70.

CLARKE, B., ARTHUR, W., HORSLEY, D. T. AND PARKIN, D. T. 1978. Genetic variation and natural selection in pulmonate molluscs. In Fretter, J. and Peake, J. (eds) Pulmonates, Vol. 2A, Systematics, Evolution and Ecology, Academic Press, London.

FORD, E. B. 1975. Ecological Genetics, 4th edn. Chapman and Hall, London.

GILLESPIE, R. G. AND TABASHNIK, B. E. 1989. What makes a happy face? Determinants of colour pattern in the Hawaiian happy face spider Theridion grallator. Heredity, 62, 355-363.

GON III, S. M. 1985. Comparative Behavioral Ecology of the Spider, Theridion grallator Simon, (Araneae: Theridiidae) in the Hawaiian Archipelago. Ph.D. Dissertation, U.C. Davis.

GREENWOOD, J. J. D. 1984. The functional basis of frequency dependent food selection. Biol. J. Linn. Soc., 23, 177-199.

GUILFORD, T. AND DAWKINS, M. S. 1987. Search images not proven: a reappraisal of recent evidence. Anim. Behav., $35,1838-1845$.
GunNarsson, B. 1985. Melanism in the spider Pityohyphantes phrygianus C. L. Koch: The genetics and the occurrence of different color phenotypes in a natural population. Heredity, 59(1), 55-62.

GUNNARSSON, B. 1987. Phenotypic variation in dark coloration in Pityohyphantes phrygianus (C. L. Koch) (Araneae: Linyphiidae). Bull Brit. Arachnol. Soc., 6(9), 369-374.

hartl, D. L. 1988. A Primer of Population Genetics, 2 nd edn. Sinauer Assoc., Inc., Sunderland, Mass.

HIPPA, H. AND OKSALA, 1. 1979. Colour polymorphism of Enoplognatha ovata (Clerck) (Araneae: Theridiidae) in western Europe. Hereditas, 90(2), 203-212.

KIMURA, M. 1983. The Neutral Theory of Molecular Evolution. Cambridge University Press, Cambridge.

LOCKeT, G. H. AND Millidge, A. F. 1953. British Spiders, Vol. 1. Ray Soc. London.

MURDOCH, W. W. AND OATEN, W. 1975. Predation and population stability. Adv. Ecol. Res., 9, 1-131.

OATEN, A. 1977. Optimal foraging in patches: a case for stochasticity. Theor. Pop. Biol, 12, 263-285.

OXFORD, G. S. 1976. The colour polymorphism in Enoplognatha ovatum (Clerck) (Araneae: Theridiidae). Heredity, 36, 369-381.

OXFORD, G. S. 1983. Genetics of colour and its regulation during development in the spider Enoplognatha ovata (Clerck) (Araneae: Theridiidae). Heredity, 51, 621-634.

OXFORD, G. S. AND SHAW, M. W. 1986. Long-term variation in colour-morph frequencies in the spider Enoplognatha ovata (Clerck) (Araneae: Theridiidae): natural selection, migration and intermittent drift. Biol. J. Linn. Soc., 27, 225-249.

PERKINS, R. C. L. 1913. Introduction (to Fauna Hawaiiensis). In Sharp, D. (ed.) Fauna Hawaiiensis Vol. 1: xv-cxxviii, Cambridge Univ. Press, Cambridge.

PIMM, S. L. AND PIMM, J. W. 1982. Resource use, competition and resource availability in Hawaiian honeycreepers. Ecology, 63, 1468-1480.

REILlO, P. R. AND WISE, D. H. 1988a. An experimental evaluation of selection on color morphs of the polymorphic Enoplognatha ovata (Araneae: Theridiidae). Evolution, 42, 1172-1189.

REIllo, P. R. AND WiSE, D. H. $1988 b$. Temporal and spatial patterns of morph frequency variation among coastal Maine populations of the polymorphic spider Enoplognatha ovata (Araneae: Theridiidae). Am. Mid. Nat., 119, 337-354.

REILlO, P. R. AND WISE, D. H. 1988c. Genetics of color expression in the spider Enoplognatha ovata (Araneae: Theridiidae) from coastal Maine. Am. Mid. Nat., 120, 318-326.

SCOTT, J. M. MOUNTAINSPRING, S., RAMSEY, F. L. AND KEPLER, C. B. 1986. Forest bird communities of the Hawaiian islands: Their Dynamics, Ecology and Conservation. Studies in Avian Biology, 9. Cooper Ornithological Society, Los Angeles.

SOKAL, R. R. AND ROHLf, F. J. 1981. Biometry: The Principles and Practice of Statistics in Biological Research. Freeman and Co., San Francisco.

TURNER, J. R. G. 1977. Butterfly mimicry: the genetical evolution of an adaptation. In: Hecht, K., Steere, W. C. and Wallace, B. (eds) Evolutionary Biology, Vol. 10, Plenum Press, New York. 